УДК 543.422.3-76.062:615.375.074

DOI https://doi.org/10.11603/2312-0967.2019.4.10685

\title{
РОЗРОБКА МЕТОДИКИ СПЕКТРОФОТОМЕТРИЧНОГО ВИЗНАЧЕННЯ РЕКОМБІНАНТНОГО РЕЦЕПТОРНОГО АНТАГОНІСТА ІНТЕРЛЕЙКІНУ-1 ЛЮДИНИ В НАПІВФАБРИКАТІ-РОЗЧИНІ
}

\author{
К. П. Мєдвєдєва ${ }^{1}$, Б. С. Бурлака ${ }^{1}$, В. В. Бугайова ${ }^{1}$, С. О. Васюк ${ }^{1}$, І. Ф. Белєнічев ${ }^{1}$, \\ Е. В. Супрун ${ }^{2}$
}

Запорізький державний медичний університет ${ }^{1}$

Національний фрармацевтичний університет², Харків

Kate-portnaya@ukr.net

\section{ІНФОРМАЦІЯ}

Надійшла до редакції / Received: 18.11.2019

Після доопрацювання / Revised: 09.12 .2019

Прийнято до друку / Accepted: 11.12 .2019

\section{Ключові слова:}

спектрофотометрія; напівсрабрикат-розчин; рекомбінантний рецепторний антагоніст інтерлейкіну-1 людини; кількісне визначення.

\begin{abstract}
АНОТАЦІЯ
Мета роботи. Розробка та валідація нової методики спектрофротометричного кількісного визначення рекомбінантного рецепторного антагоніста інтерлейкіну-1 людини (РPAІЛ-1) у напівфрабрикаті-розчині.

Матеріали і методи. У дослідженні використано напівфрабрикат-розчин (PPAІЛ - 1 - 50 мг, динатрію едетат - 0,12 мг, натрію дигідрофросфрат дигідрат 7,8 мг, полісорбат-20 - 0,10 мг, вода для ін'єкцій до 1 мл), а як розчинник воду очищену. Аналітичне обладнання: спектрофротометр Specord 200, ваги електронні АВT-120-5DM.

Результати й обговорення. Розроблено нову, просту методику кількісного визначення PPAIЛ-1 у напівфобрикаті-розчині методом спектрофотометрії в УФ-області, яка базується на вимірюванні оптичної густини водного розчину сполуки при 280 нм. Методика була валідована за такими характеристиками, як лінійність, прецизійність, правильність, специфічність та робасність. Лінійна залежність абсорбції від концентрації знаходиться в діапазоні 0,61,1 мг/мл. Аналіз прогнозованої повної невизначеності аналізу свідчить про можливість застосування розробленої методики в інших лабораторіях.

Висновки. Розроблено та валідовано методику визначення вмісту РРАІЛ-1 у напівфабрикаті-розчині згідно з вимогами ДФУ. Доведено, що за такими валідаційними характеристиками, як лінійність, специфічність, прецизійність, правильність та робасність методика є коректною.
\end{abstract}

Вступ. Контроль якості відіграє важливу роль на всіх етапах життєвого циклу лікарських засобів - від розробки і до промислового виробництва. Сучасні фрізико-хімічні методи аналізу широко використовуються для оцінки якості субстанцій та лікарських засобів. Відомою є методика кількісного визначення РPАІЛ-1 в комбінації з цефтріаксоном у лікарських формах методом ВЕРX [1].

Спектрофротометрія в УФ-області як метод кількісного визначення, відрізняється простотою, до- ступністю, експресністю та чутливістю. Таким чином, зазначений спосіб може бути представлений як один із можливо доступних. Згідно з вимогами ДФУ будь-яка аналітична методика, яка вирішує офріційні задачі, повинна бути валідована [2-4]. Тому метою нашої роботи стали розробка та валідація нової методики кількісного визначення PPAІЛ-1 у напівфабрикаті-розчині методом абсорбційної спектрофротометрії. 


\section{Analysis of drugs}

Матеріали і методи. Напівфрабрикат-розчин PPAІЛ-1, отриманий відповідно до договору про науково-практичне співробітництво з Національним фрармацевтичним університетом (CAS \#143090-92-0 Interleukin1 receptor antagonist, purity $\geq 98 \%$, ФДУП «Державний НДІ ОЧБ» ФМБА, реєстраційний номер стандарту якості лікарського засобу - ЛРС-007452/10-300710). Для вимірювання оптичної густини використовували спектрофротометр Specord 200 (Analytik jena, Німеччина). Зважування хімічних допоміжних речовин проводили за допомогою електронних аналітичних ваг АВT-120-5DM. Усі процедури приготування розчинів виконували за допомогою мірного посуду класу А. Як розчинник використовували воду очищену.

Загальна методика визначення вмісту діючої речовини

10,00 мл розчину-напівфрабрикату з концентрацією 50 мг/мл вміщують у мірну колбу ємністю 50,00 мл, доводять до позначки водою очищеною і перемішують. 0,90 мл одержаного розчину вміщують у мірну колбу на 10,00 мл і доводять тим самим розчинником до позначки. Абсорбцію отриманого розчину вимірюють при довжині хвилі 280 нм (компенсаційний розчин - вода очищена). Паралельно проводять визначення абсорбції робочого стандартного розчину (0,9 мг/мл). Концентрацію РРАІЛ-1 (мг/мл) розраховують за фрормулою:

$$
\mathrm{C}=\frac{\mathrm{A}_{\mathrm{i}}}{\mathrm{A}_{\mathrm{St}}} \times 100,
$$

де $A_{i}$ - оптична густина досліджуваного розчину; $\mathrm{A}_{\mathrm{st}}$ - оптична густина розчину порівняння.

Результати й обговорення. При отриманні УФспектра розчину аналізованої сполуки в ділянці від 200 нм до 360 нм було виявлено, що досліджуваний розчин має декілька максимумів поглинання, але лише один із них, а саме при 280 нм, придатний для розробки методики кількісного визначення (рис. 1).

Валідація методики

На етапі встановлення придатності розробленої методики, для оцінки якості аналізованої речовини в розчині, було проведено валідацію згідно з вимогами ДФУ [2-4]. Таким чином, вивчали лінійність, діапазон застосування, прецизійність, правильність, специфрічність та робасність.

Лінійність, прецизійність, правильність та діапазон застосування

Визначення лінійності, прецизійності та правильності проводили одночасно відповідно до рекомендацій ДФУ для методу стандарту [2]. 3 цією метою для кількісного випробування було вивчено 9 точок (по 3 повтори) в межах досліджуваного діапазону методики. Для оцінки точності і правильності було використано результати, одержані при дослідженні лінійності (табл. 1).

Згідно з законом Бугера-Ламберта-Бера лінійна залежність спостерігалась у межах 66,6 - 122,2 \% (100 \% - 0,9 мг/мл) від номінального вмісту рекомбінантного рецепторного антагоніста інтерлейкіну-1 людини в розчині, що є не меншим від мінімально допустимого діапазону застосування методики кількісного визначення [2-4].

Аліквоти розчину-напівфрабрикату, що відповідають концентраціям у межах 0,6-1,1 мг/мг, переносять в мірну колбу на 10,00 мл з подальшим доведенням водою очищеною до позначки, перемішуванням і вимірюванням абсорбції приготовлених розчинів. На основі отриманих результатів будують графрік залежності абсорбції від концентрації РPAІЛ-1 в розчині (рис. 2). Числові показники лінійності розраховано методом найменших квадратів. Результати, наведені в таблиці 1, свідчать, що методика є лінійною в об-

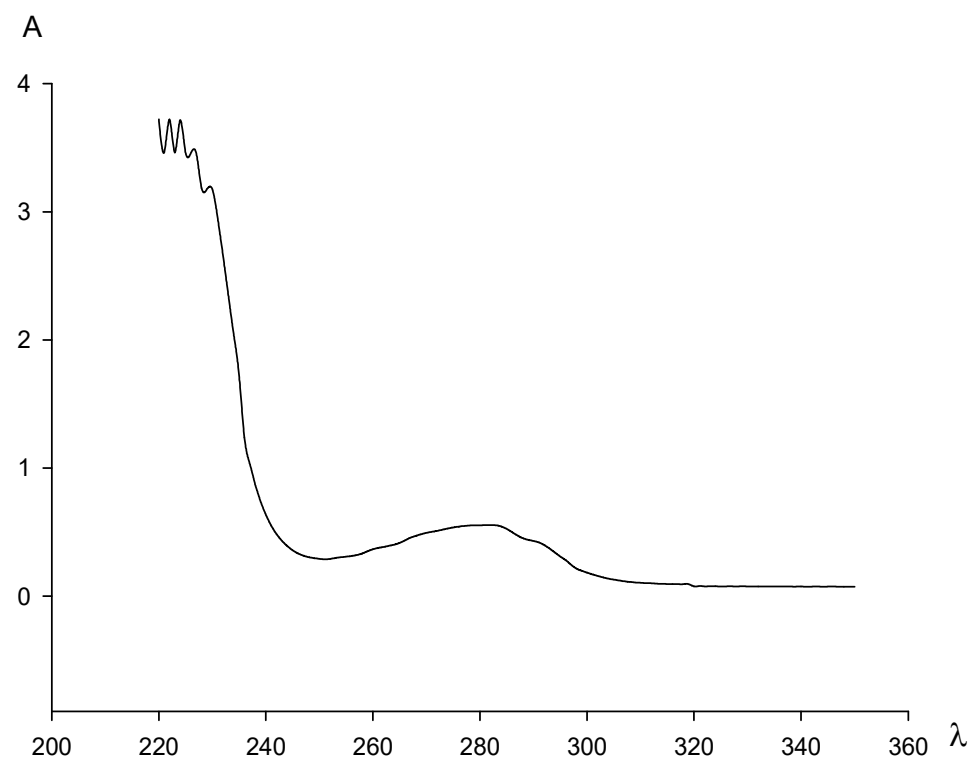

Рис. 1. УФ-спектр випробуваного розчину РPAІЛ-1 (компенсаційний розчин - вода очищена).

ISSN 2312-0967. Фармацевтичний часопис. 2019. № 4 
Таблиця 1

Визначення лінійності, прецизійності та правильності методики кількісного визначення досліджуваної речовини

\begin{tabular}{|c|c|c|c|}
\hline № & $\overline{X i}$ & $\overline{Y i}$ & $\bar{Z}$ \\
\hline 1 & 66,67 & 67,73 & 101,6 \\
\hline 2 & 72,22 & 72,69 & 100,6 \\
\hline 3 & 77,78 & 77,97 & 100,2 \\
\hline 4 & 83,33 & 84,50 & 101,6 \\
\hline 5 & 88,89 & 90,58 & 101,9 \\
\hline 6 & 94,44 & 94,53 & 100,1 \\
\hline 7 & 100,0 & 100,0 & 100,0 \\
\hline 8 & 111,1 & 113,3 & 101,9 \\
\hline 9 & 122,2 & 122,4 & 100,2 \\
\hline \multicolumn{4}{|c|}{ Лінійність } \\
\hline & Показник & $\begin{array}{c}\text { Критерії } \\
\text { (для допусків } 90 \text { - } 110 \text { \%) }\end{array}$ & $\begin{array}{c}\text { Значення та } \\
\text { висновок }\end{array}$ \\
\hline & r & $\geq 0,9583$ & $\begin{array}{c}0,9989 \\
\text { Відповідає }\end{array}$ \\
\hline & $\underset{a}{a}=t(95 \%, 7) * S_{a}$ & $\begin{array}{c}\text { 1. Статистична незначущість } \\
\mathrm{a} \leq \mathrm{t}(95 \%, 7) * \mathrm{~S}_{\mathrm{a}}=1,89 * \mathrm{~S}_{\mathrm{a}} \\
\text { 2. Практична незначущість } \\
|\mathrm{a}| \leq 3,07\end{array}$ & $\begin{array}{c}0,6673 \\
0,6673 \leq 3,056 \\
\text { Відповідає } \\
\text { Відповідає }\end{array}$ \\
\hline & $b$ & - & 1,0037 \\
\hline & $\mathrm{S}_{\mathrm{a}}$ & - & 1,6132 \\
\hline & $\mathrm{S}_{\mathrm{b}}$ & - & 0,0175 \\
\hline & $\mathrm{S}_{x^{\prime} 0}(\%)$ & $\begin{array}{c}0,8999 \\
\leq \Delta \operatorname{As}(\%) / t(95 \% ; 7)=1,6890\end{array}$ & Відповідає \\
\hline \multicolumn{4}{|c|}{ Прецизійність та правильність } \\
\hline & Показник & $\begin{array}{c}\text { Критерії } \\
\text { (для допусків } 90 \text { - } 110 \text { \%) }\end{array}$ & $\begin{array}{c}\text { Значення та } \\
\text { висновок }\end{array}$ \\
\hline Cepє & $\bar{Z} \%$ & - & 100,9 \\
\hline & сне стандартне відхилення, $\mathrm{S}_{\mathrm{z}}, \%$ & $\leq 1,690$ & $\begin{array}{c}\text { 0,8291 } \\
\text { Відповідає }\end{array}$ \\
\hline & $\begin{array}{r}\text { Відносний довірчий інтервал } \\
\Delta_{\text {prec }} \%=\mathrm{t}(95 \%, 8) * \mathrm{~S}_{\mathrm{z}} \%\end{array}$ & $\leq 3,200$ & $\begin{array}{c}1,542 \\
\text { Відповідає }\end{array}$ \\
\hline Сист & тична похибка $\delta_{\text {tot }}=|\bar{z}-100|$ & 一 & 0,9000 \\
\hline Якь & $\begin{array}{r}\text { терій незначущості систематичної } \\
\text { похибки } \\
(1) \delta_{\text {tot }} \leq \Delta_{\text {prec }} / 3 \\
\text { ее виконується (1), то (2) } \delta_{\text {tot }} \leq \max _{\delta_{\text {tot }}}\end{array}$ & $\begin{array}{l}\leq 0,5140 \\
\leq 1,020\end{array}$ & $\begin{array}{l}\text { Не відповідає } \\
\text { Відповідає }\end{array}$ \\
\hline
\end{tabular}

раному діапазоні концентрацій і відповідає вимогам ДФУ.

Як видно з результатів аналізу, методика є точною, оскільки однобічний довірчий інтервал не перевищує максимально допустиму невизначеність аналізу, і правильною, бо систематична похибка статистично не відрізняється від нуля, тобто справжнє значення величини не виходить за межі встановленого довірчого інтервалу [5].

Робасність

На етапі розробки спектрофотометричної методики проводили паралельно перевірку стабільності аналізованого розчину і розчину порівняння в нормалізованих координатах шляхом вимірювання їхньої

ISSN 2312-0967. Pharmaceutical review. 2019. № 4 


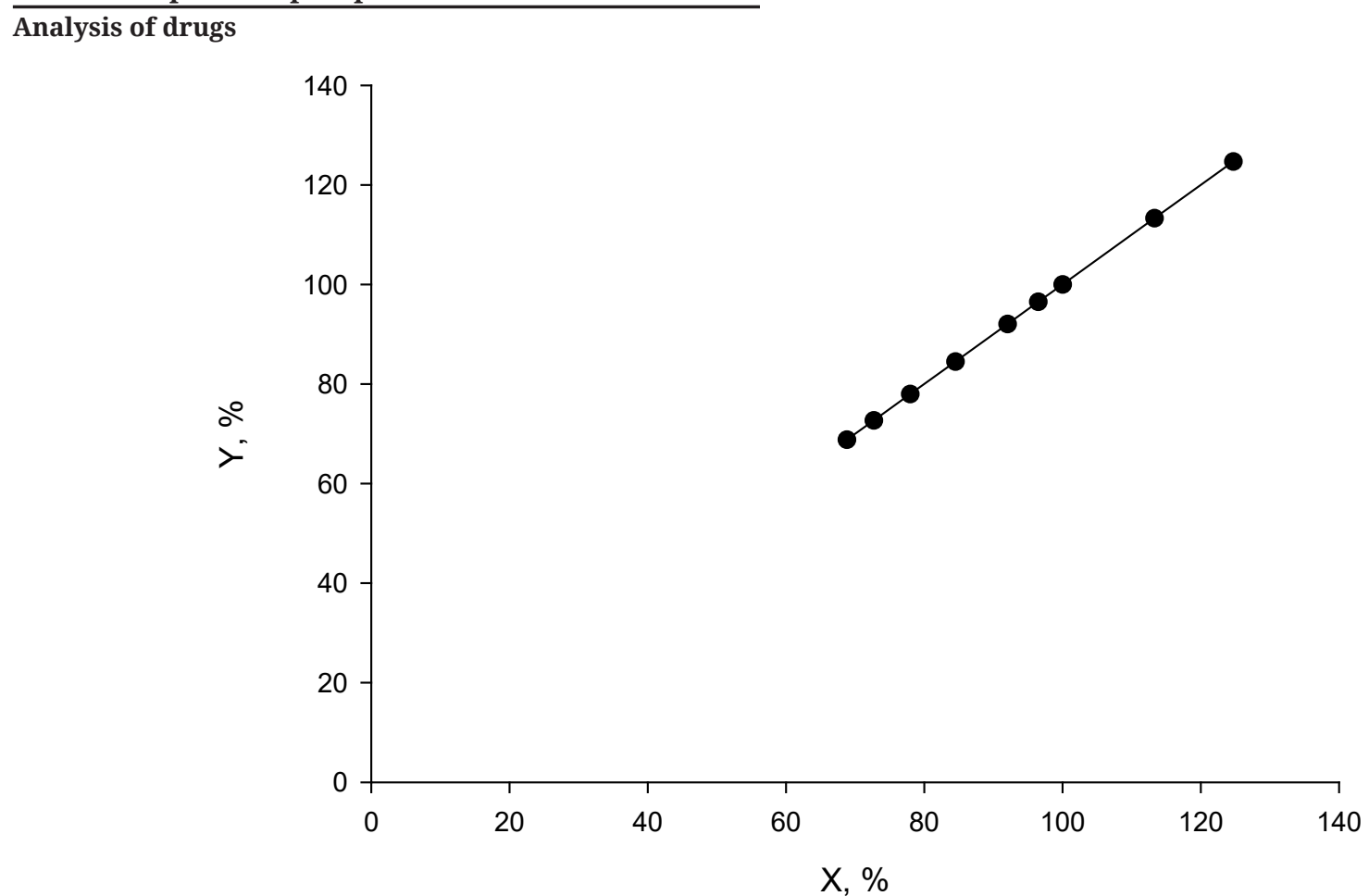

Рис. 2. Графрік лінійної залежності абсорбції від концентрації РРАІЛ-1 в розчині.

абсорбції впродовж 45 хвилин після приготування, кожні 15 хвилин з вийманням кювети (рис. 3).

3 отриманих даних випливає, що розчини стабільні протягом визначеного проміжку часу [3].

\section{Специфрічність}

Перевірка специфрічності була здійснена шляхом доведення незначущості впливу гранично допустимого вмісту натрію дигідрофросорату на аб- сорбцію вимірюваного розчину порівняно з максимально допустимою невизначеністю аналізу $\max \Delta_{\text {As. }}$ Такий вибір був зумовлений його найбільшою кількістю у досліджуваному об'єкті (15\%) відносно вмісту аналізованої речовини, при тому, що сумарний вміст інших допоміжних речовин не перевищує 0,5 \%. Тому для приготування розчину порівняння брали 0,01560 г натрію дигідросросфра-

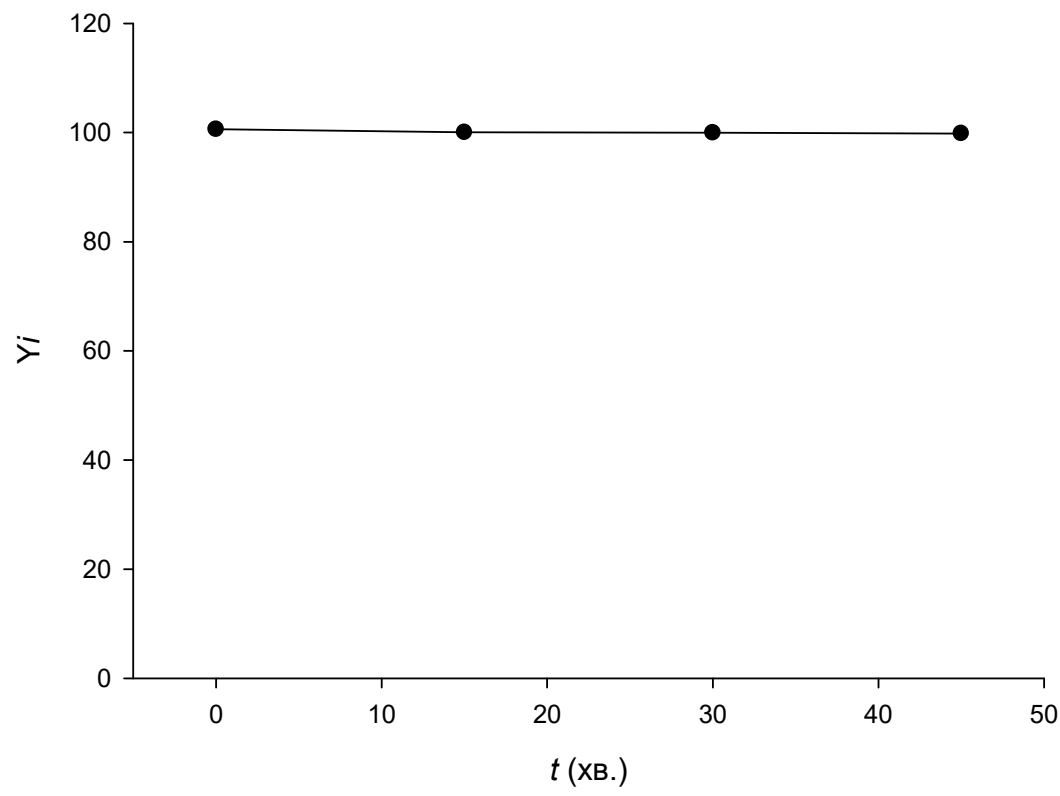

Рис. 3. Результати визначення РРАІЛ-1, отримані при вивченні стабільності стандартного робочого розчину в часі.

ISSN 2312-0967. Фармацевтичний часопис. 2019. № 4 
ту, вміщували його до мірної колби на 100,0 мл, розчиняли і доводили до позначки очищеною водою. Вимірювання абсорбції $\left(\mathrm{A}_{\text {blank }}\right)$ розчину проводили тричі. Паралельно визначали абсорбцію розчину робочого стандарту $\left(\mathrm{A}_{\mathrm{st}}\right)$.

Як видно з кривої абсорбції (рис. 4), вимога специфрічності виконується - натрію дигідрофросфрат не здійснює значущого впливу на значення абсорбції аналізованої речовини у розчині. Це доводить, що вимірювання абсорбції можна виконувати відносно компенсаційного розчину - води очищеної [6].

Повна невизначеність аналітичної методики

Для оцінки коректності відтворення розробленої методики в інших лабораторіях було проведено розрахунок повної невизначеності результатів вказаної методики кількісного визначення. Ії̈ значення повинно бути менше від максимально допустимої невизначеності $\left(\triangle_{A S}\right)$.
Оскільки для процедури вимірювання абсорбції використовують два розчини, один із яких розчин порівняння, і здійснюють три паралельних вимірювання з вийманням кювети, значення невизначеності кінцевої аналітичної операції $\left(\Delta_{F A O}\right)$ дорівнює 0,70\% $1,34 \mathrm{RSD}_{\mathrm{A}}=1,340,52=0,70 \%$ [5].

Прогноз повної невизначеності розраховували за формулою:

$$
\Delta_{\mathrm{As}}=\sqrt{\Delta_{\mathrm{SP}}^{2}+\Delta_{\mathrm{FAO}}^{2}},
$$

де $\Delta_{S P}-$ невизначеність пробопідготовки;

$\Delta_{F A O}$ - прогнозована невизначеність кінцевої аналітичної операції.

Розрахунок невизначеності пробопідготовки наведено в таблиці 2.

Отже, прогнозована повна невизначеність аналізу (1,35 \%) не перевищує максимально допустиму невизначеність методики (3,20 \%) і методика зможе бути відтворена в інших лабораторіях $[7,8]$.

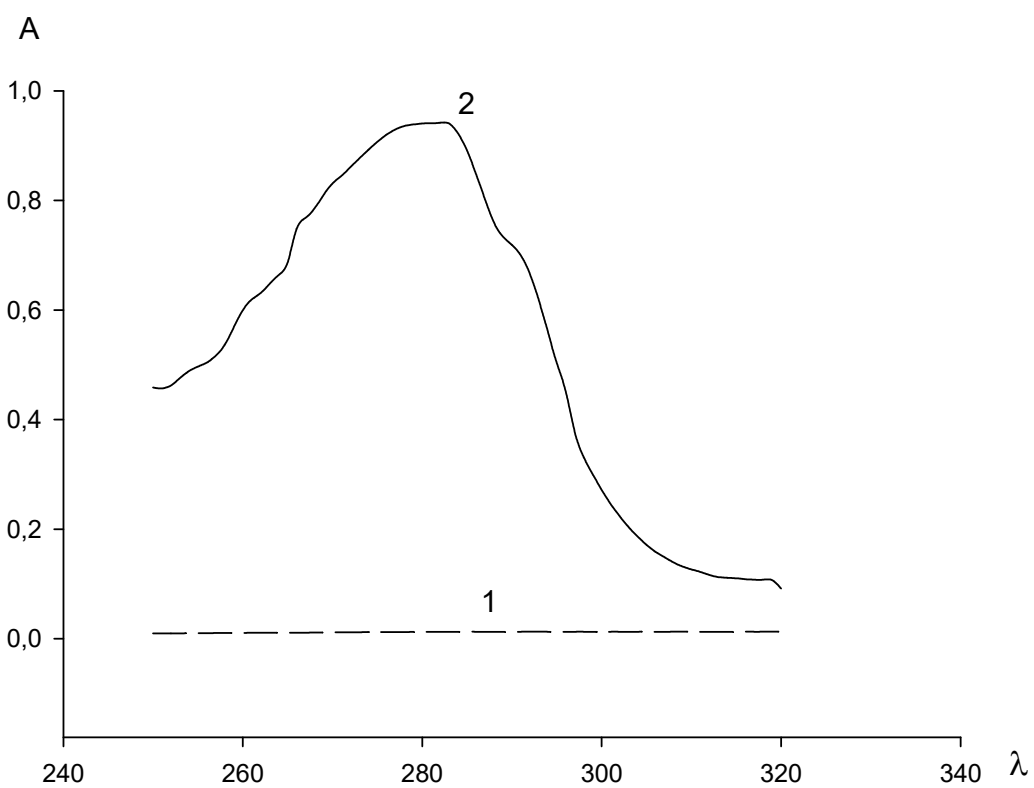

Рис. 4. Спектри поглинання стандартного робочого розчину (2) і розчину натрію дигідрофоссрату (1) відносно компенсаційного розчину - води очищеної.

Таблиця 2

Розрахунок невизначеності пробопідготовки методики визначення вмісту рекомбінантного рецепторного антагоніста інтерлейкіну-1 людини

\begin{tabular}{|c|c|c|}
\hline Операція пробопідготовки & $\begin{array}{c}\text { Параметр } \\
\text { розрахункової } \\
\text { формули }\end{array}$ & Невизначеність, \% \\
\hline 1 & 2 & 3 \\
\hline \multicolumn{3}{|c|}{ Досліджуваний розчин } \\
\hline Взяття аліквоти напівфрабрикату-розчину піпеткою на 10 мл & 10 & 0,25 \\
\hline Доведення до об'єму в мірній колбі ємністю 50 мл & 50 & 0,17 \\
\hline $\begin{array}{l}\text { Взяття аліквоти розведення напівфрабрикату-розчину піпеткою } \\
\text { на } 2 \text { мл }\end{array}$ & 2 & 0,57 \\
\hline
\end{tabular}

ISSN 2312-0967. Pharmaceutical review. 2019. № 4 
Аналіз лікарських препаратів

Analysis of drugs

Продовження табл. 2

\begin{tabular}{|c|c|c|}
\hline 1 & 2 & 3 \\
\hline Доведення до об'єму в мірній колбі ємністю 10 мл & 10 & 0,50 \\
\hline \multicolumn{3}{|l|}{ Розчин порівняння } \\
\hline Взяття аліквоти напівфрабрикату-розчину піпеткою на 10 мл & 10 & 0,25 \\
\hline Доведення до об'єму в мірній колбі ємністю 50 мл & 50 & 0,17 \\
\hline $\begin{array}{l}\text { Взяття аліквоти розведення напівфрабрикату-розчину піпеткою } \\
\text { на } 2 \text { мл }\end{array}$ & 2 & 0,57 \\
\hline Доведення до об'єму в мірній колбі ємністю 10 мл & 10 & 0,50 \\
\hline \multicolumn{3}{|c|}{$\Delta_{\mathrm{SP}}=\sqrt{0,25^{2}+0,17^{2}+0,57^{2}+0,50^{2}+0,25^{2}+0,17^{2}+0,57^{2}+0,50^{2}}=1,15 \%$} \\
\hline
\end{tabular}

Висновок. Розроблено та валідовано експресну методику визначення вмісту РPAІЛ-1 в напівфрабрикатірозчині методом спектрофотометрії в УФ-ділянці спектра. Запропонована методика є лінійною, прецизійною, правильною, робасною і специфрічною і тому, згідно з вимогами ДФУ, може бути використана для контролю якості досліджуваного напіворабрикату-розчину.

Конфрлікт інтересів: відсутній.

Conflicts of interest: authors have no conflict of interest to declare.

\title{
THE DEVELOPMENT OF METHOD FOR THE SPECTROPHOTOMETRIC DETERMINATION OF A RECOMBINANT HUMAN INTERLEUKIN-1 RECEPTOR ANTAGONIST IN A SEMI-FINISHED SOLUTION
}

\author{
K. P. Miedviedieva ${ }^{1}$, B. S. Burlaka ${ }^{1}$, V. V. Buhaiova ${ }^{1}$, S. O. Vasyuk ${ }^{1}$, I. F. Belenichev ${ }^{1}$, E. V. Suprun ${ }^{2}$ \\ Zaporizhzhia State Medical University ${ }^{1}$ \\ National University of Pharmacy², Kharkiv \\ Kate-portnaya@ukr.net
}

The aim of the work. The development and validation of the new spectrophotometric method for the quantitative determination of a recombinant human interleukin-1 receptor antagonist (IL-1RA) in a semi-finished solution.

Materials and Methods. Studying object - a semi-finished solution (IL-1RA - 50 mg, disodium edetate - 0,12 mg, sodium dihydrophosphate dihydrate - 7,8 mg, polysorbate-20-0,10 mg, water for injection up to $1 \mathrm{ml})$. As a solvent, purified water was used. Analytical equipment: spectrophotometer Specord 200, electronic scales ABT-120-5DM.

Results and Discussion. A new, simple method for the quantitative determination of a recombinant human IL-1RA in a semi-finished solution with the method of UV spectrophotometry has been developed, that is based on the measuring of the absorption of the aqueous solution at $280 \mathrm{~nm}$. The method was validated for linearity, accuracy, precision, specificity, and robustness. The linear dependence of absorption on concentration was found in the range of 0,6 to $1,1 \mathrm{mg} / \mathrm{ml}$. The analysis of the predicted total indeterminacy of the analysis indicates the possibility of its application in other laboratories.

Conclusions. The development and validation of the spectrophotometric method of quantitative determination of a recombinant human IL-1RA in a semi-finished solution according to the standardized validation procedure was carried out. It is proved that according to such validation characteristics as linearity, precision, correctness and robustness, the method is correct.

Key words: spectrophotometry; solution; recombinant human interleukin-1 receptor antagonist; quantitative determination.

ISSN 2312-0967. Фармацевтичний часопис. 2019. № 4 


\title{
РАЗРАБОТКА МЕТОДИКИ СПЕКТРОФОТОМЕТРИЧЕСКОГО ОПРЕДЕЛЕНИЯ РЕКОМБИНАНТНОГО РЕЦЕПТОРНОГО АНТАГОНИСТА ИНТЕРЛЕЙКИНА-1 ЧЕЛОВЕКА В ПОЛУФАБРИКАТЕ-РАСТВОРЕ
}

\author{
Е. П. Медведева ${ }^{1}$, Б. С. Бурлака ${ }^{1}$, В. В. Бугаёва ${ }^{1}$, С. А. Васюк ${ }^{1}$, И. Ф. Беленичев ${ }^{1}$, Э. В. Супрун ${ }^{2}$ \\ Запорожский государственный медицинский университет ${ }^{1}$ \\ Национальный фрармацевтический университет², Харьков \\ Kate-portnaya@ukr.net
}

Цель работы. Разработка и валидация новой методики спектрофотометрического количественного определения рекомбинантного рецепторного антагониста интерлейкина-1 человека (РРАИЧ-1) в полуфабрикате-растворе.

Материалы и методы. В исследовании использованы полуфабрикат-раствор (РРАИЧ-1 - 50 мг, динатрия эдетат - 0,12 мг, натрия дигидросроссрат дигидрат - 7,8 мг, полисорбат-20 - 0,10 мг, вода для инъекций до 1 мл), как растворитель - вода очищеная. Аналитическое оборудование: спектрофотометр Specord 200, весы электронные ABT-120-5DM.

Результаты и обсуждение. Разработана новая, простая методика количественного определения РРАИЧ-1 в полуфабрикате-растворе методом спектрофотометрии в УФ-области, основанная на измерении оптической плотности водного раствора соединения при 280 нм. Методика была валидирована согласно таким характеристикам, как линейность, прецизионность, правильность, специфичность и робастность. Линейная зависимость абсорбции от концентрации находится в диапазоне 0,6-1,1 мг/мл. Анализ прогнозируемой полной неопределенности анализа свидетельствует о возможности применения разработанного метода в других лабораториях.

Выводы. Разработана и валидирована методика определения содержания РРАИЧ-1 в полуфабрикатерастворе согласно требованиям ГФУ. Доказано, что по таким валидационным характеристикам, как линейность, специоичность, прецизионность, правильность и робастность, методика является корректной.

Ключевые слова: спектрофотометрия; полуфабрикат-раствор; рекомбинантный рецепторный антагонист интерлейкина-1 человека; количественное определение.

\section{Список літератури}

1. Stability and compatibility of anakinra with ceftriaxone sodium injection in $0.9 \%$ sodium chloride or $5 \%$ dextrose injection / M. C. Nahata, R. S. Morosco, B. K. Sabados [et al.]. // Journal of Clinical Pharmacy and Therapeutics - 1997. - No. 22. - Р. 167-169.

2. Державна Фармакопея України: в 3 т. / ДП «Український науковий фармакопейний центр якості лікарських засобів». - 2-е вид. - Х. : Державне підприємство «Український науковий фрармакопейний центр якості лікарських засобів», 2015. - Т. 1. - 1128 с.

3. Державна Фармакопея України: в 3 т. / Державне підприємство «Український науковий срармакопейний центр якості лікарських засобів». - 2-е вид. - Харків : Державне підприємство «Український науковий фармакопейний центр якості лікарських засобів». 2014. - T. 3. - 732 c.

4. Державна Фармакопея України / Державне підприємство «Науково-експертний фрармакопейний центр». - 1-е вид. - Харків : РІРЕГ, 2001. - 556 с. - Доповнення 1. - 2004. - 520 с. - Доповнення 2. - Харків : Державне підприємство «Науково-експертний фрар-

\section{References}

1. Nahata MC, Morosco RS, Sabados BK, Weber TR. Stability and compatibility of anakinra with ceftriaxone sodium injection in $0.9 \%$ sodium chloride or $5 \%$ dextrose injection. Journal of Clinical Pharmacy and Therapeutics. 1997;22: 167-9. макопейний центр». - 2008. - 620 с. - Доповнення 3. - 2009. - 280 с. - Доповнення 4. - 2011. - 540 с.

5. Гризодуб А. И. Стандартизованные процедуры валидации методик контроля качества лекарственных средств. - Х. : Государственное предприятие «Украинский научный фрармакопейный центр качества лекарственных средств», 2016. -396 с.

6. Воспроизводимость фрармакопейных спектрофотометрических методик количественного определения лекарственных средств в разных лабораториях / А. И. Гризодуб, Н. Н. Зволинская, Н. Н. Архипова [и др.] // Фармаком. - 2004. - № 2. - С. 20-34.

7. Гризодуб А. И. Валидация спектрофотометрических методик количественного анализа лекарственных средств в соответствии с требованиями ГФУ / А. И. Гризодуб // Фармаком. - 2002. - № 3. - С. 42-50.

8. Стандартизованная процедура валидации методик количественного анализа лекарственных средств методом стандарта / А. И. Гризодуб, Д. А. Леонтьев, Н. Н. Денисенко, Ю. В. Подпружинников // Фармаком. - 2004. - № 3. - С. 3-17.

Retrieved from: https://doi.org/10.1046/j.13652710.1997.95275952.x

2. The State Pharmacopoeia of Ukraine: in 3 vol. Kharkiv: Ukrainian Scientific Pharmacopoeia Center of Quality of Medicinal Products. Ed.2. [Державна Фармакопея

ISSN 2312-0967. Pharmaceutical review. 2019. № 4 


\section{Analysis of drugs}

України: в 3 т. / ДП «Український науковий фармакопейний центр якості лікарських засобів». 2-е вид.] Kharkiv: Ukrainian Scientific Pharmacopoeia Center of Quality of Medicinal Products.2014; Ukrainian.

3. The State Pharmacopoeia of Ukraine: in 3 vol. Kharkiv: Ukrainian Scientific Pharmacopoeia Center of Quality of Medicinal Products. Ed.2. [Державна Фармакопея України: в 3 т. / Державне підприємство «Український науковий фрармакопейний центр якості лікарських засобів». - 2-е вид.] Kharkiv: Ukrainian Scientific Pharmacopoeia Center of Quality of Medicinal Products. 2014. Ukrainian.

4. The State Pharmacopoeia of Ukraine. [Державна фрармакопея України] Kharkiv: Ukrainian Scientific Pharmacopoeia Center of Quality of Medicinal Products. 1 ed. X; 2001; 556 p. Ed. 1. 2004; 520 p. Ed. 2. Kharkiv: Ukrainian Scientific Pharmacopoeia Center of Quality of Medicinal Products.2008; 620 p. Ed 3. 2009;280 p. Ed. 4.2011; 540 p. Ukrainian.

5. Grisodub Al. Standardized procedures for the validation of drug quality control methods. [Стандартизованные процедуры валидации методик контроля качества лекарственных средств] Kharkiv: Ukrainian Scientific Pharmacopoeia Center of Quality of Medicinal Products]. 2016. Russian.

6. Grisodub Al, Zvolinskaya NN, Arhipova NN. [Reproducibility of pharmacopeia spectrophotometric methods of quantitative determination of drugs in different laboratories]. Farmakom. 2004;2: 20-14. Ukrainian.

7. Grisodub AI. [Validation of drug quality control methods according to SPU]. Farmakom. 2002;3: 42-8. Ukrainian.

8. Grisodub Al, Leontiev DA, Podpruzhynnikov YuV. [Standardized procedures for the validation of drug quality control methods using standard method]. Farmakom. 2004;3: 3-14. Ukrainian.

\section{Відомості про авторів:}

Мєдвєдєва К. П. - канд. фрармац. н., старший викладач кафедри аналітичної хімії, Запорізький державний медичний університет, Запоріжжя, Україна. E-mail: kate-portnaya@ukr.net, ORCID 0000-0001-7260-5728

Бурлака Б. С. - канд. фрармац. н., доцент кафедри технології ліків, Запорізький державний медичний університет, Запоріжжя, Україна. E-mail: burlakabogdan@gmail.com, ORCID 0000-0003-4539-7331

Бугайова В. В. - викладач-стажист кафедри аналітичної хімії, Запорізький державний медичний університет, Запоріжжя, Україна. E-mail: bugaevavladlena@gmail.com, ORCID 0000-0003-0444-746X

Васюк С. О. - д. фрармац. н., профресор, завідувач кафедри аналітичної хімії, Запорізький державний медичний університет, Запоріжжя, Україна. E-mail: svitlanavasyuk@gmail.com, ORCID 0000-0002-1569-9374

Белєнічев І. Ф. - д. біол. н., професор, завідувач кафедри фрармакології та медичної рецептури, Запорізький державний медичний університет, Запоріжжя, Україна. E-mail: Ifb1914@mail.ru, ORCID 0000-0003-1273-5314

Супрун Е. В. - д. мед. н., професор кафедри загальної фрармації та безпеки ліків ІПкСФ НФаУ, Харків, Україна. E-mail: elinasuprun202@gmail.com, ORCID 0000-0001-8598-8043

\section{Information about the authors}

Miedviedieva K. 'P. - PhD (Pharmaceutical Sciences), Senior Lecturer of the Analytical Chemistry Department, Zaporizhzhia State Medical University, Zaporizhzhia, Ukraine. E-mail: kate-portnaya@ukr.net, ORCID 0000-0001-7260-5728

Burlaka B. S. - PhD (Pharmaceutical Sciences), Associate Professor of the Drug Technology Department, Zaporizhzhia State Medical University, Zaporizhzhia, Ukraine. E-mail: burlakabogdan@gmail.com, ORCID 0000-0003-4539-7331

Buhaiova V. V. - Assistant Lecturer of the Analytical Chemistry Department, Zaporizhzhia State Medical University, Zaporizhzhia, Ukraine. E-mail: bugaevavladlena@gmail.com, ORCID 0000-0003-0444-746X

Vasyuk S. O. - DS (Pharmaceutical Sciences), Professor, Chief of the Analytical Chemistry Department, Zaporizhzhia State Medical University, Zaporizhzhia, Ukraine. E-mail: svitlanavasyuk@gmail.com, ORCID 0000-0002-1569-9374

Belenichev I. F. - DS (Biological Sciences), Professor, Chief of the Pharmacology and Medical Prescription Department, Zaporizhzhia State Medical University, Zaporizhzhia, Ukraine. E-mail: Ifb1914@mail.ru, ORCID 0000-0003-1273-5314 Suprun E. V. - MD, Professor of General Pharmacy and Safety of Drugs IPHPQI NUPh, Kharkiv, Ukraine. E-mail: elinasuprun202@gmail.com, ORCID 0000-0001-8598-8043 